DOI: https://doi.org/10.32839/2304-5809/2020-12-88-24

уДК 336.27

Західна О.P., Баїк А.І., Огірко О.Т.

Львівський національний університет імені Івана Франка

\title{
ДЕРЖБОРГ УКРАЇНИ ТА ЙОГО ПОГАШЕННЯ
}

\begin{abstract}
Анотація. У статті проаналізовано сутність поняття “державного боргу” згідно поглядів вітчизняних та іноземних науковців. Досліджено стан та динаміку державного боргу України протягом останніх років. Показана структура державного боргу України згідно поділу його на зовнішній та внутрішній, а також розраховано частки зовнішнього та внутрішнього боргу в загальній сумі державного та гарантованого державою боргу. Визначено структуру зовнішньої заборгованості державного бюджету згідно об'єкта, що надавав позику. Зазначено перелік іноземних організацій, які є головними кредиторами України на сучасному етапі. Згідно даних Державної казначейської служби України визначено динаміку погашення та обслуговування державного боргу. Розглянуто проблеми виникнення та збільшення державного боргу, та запропоновано шляхи їх вирішення.
\end{abstract}

Ключові слова: державний борг, гарантований державний борг, погашення боргу, обслуговування боргу, внутрішній борг, зовнішній борг.

Zahidna Oksana, Baik Anastasiia, Ohirko Olena Lviv Ivan Franko National University

\section{STATE DEBT OF UKRAINE AND ITS REPAYMENT}

Summary. The article examines the essence of the concept of "public debt" according to the Budget Code of Ukraine. The theoretical concept of public debt is analyzed and defined according to the views of domestic and foreign scholars. The state and dynamics of Ukraine 's public debt in recent years have been studied. The structure of Ukraine's public debt is analyzed according to its division into external and internal, and the shares of external and internal debt in the total amount of public and state-guaranteed debt are determined. The structure of the external debt of the state budget according to the object that provided the loan is determined. The main reasons for the emergence of external state debt are analyzed, the current state of the state debt and its impact on the socio-economic development of Ukraine in the conditions of the destructive processes taking place are investigated. New approaches to modernization of public debt servicing of Ukraine have been established. The main attention is paid to the main external creditors of Ukraine, the role of international financial organizations in the international economic activity of Ukraine is revealed. The list of foreign organizations that are the main creditors of Ukraine at the present stage is studied. According to the data The dynamics of repayment and servicing of public debt has been determined by the State Treasury Service of Ukraine. he statistics on public debt in Ukraine have been systematized. here are a number of coefficients characterizing the level of debt of the country at the present stage. An assessment of the structure of government debt in terms of currencies is made, which allows to calculate and analyze the share of government debt in foreign currency in the total amount of debt. An estimate of the ratio of government debt and government guaranteed debt to exports in recent years has been calculated and evaluated. Effective management of the external public debt will help to avoid crises and overload the expenditures of the state budget and, as a consequence, to improve the standard of living of the population and to restore the status of Ukraine as a reliable and promising partner in the international capital markets. The problems of emergence and increase of the state debt are considered, and the ways of their decision are offered.

Keywords: public debt, guaranteed public debt, debt repayment, debt service, domestic debt, external debt.

Постановка проблеми. В сучасних умовах і розвиненим країнам, і країнам, що розвиваються, притаманна тенденщія до постійного зростання державного боргу. За умов виваженої політики у сфері використання зовнішніх запозичень додатково залучені кошти дозволяють збільшити сукупні витрати при нижчому рівні національного доходу. До негативних наслідків впливу зовнішньої заборгованості в результаті сплати відсотків за кредити належать загострення соціальних проблем суспільства, яке виникає внаслідок зменшення державних видатків, спадання економічної активності, спричинене збільшенням податків. Однак, на сьогодні залишається не сформованим единий погляд щодо впливу державного боргу на економічний розвиток країни, а також не сорормована досконала політика погашення державного боргу. Саме тому набувають актуальності питання теоретичного дослідження особливостей вимірювання зовнішнього державного боргу та аналізу особливостей його погашення.
Аналіз останніх досліджень і публікацій. Особливості державного боргу та незбалансованості бюджету досліджували такі вчені: Д. Рікардо, А. Сміт, М. Браунриг, С. Вайнтрауб, Х. Джонсон та інші. Теоретичні основи державного боргу та питання щодо його погашення висвітлюються в працях таких українських вчених, як: О.Д. Василик, А.С. Гальчинський, Г.Н. Климко, В.В. Корнєев, О.В. Плотніков, І.Я. Софіщенко, B.M. Суторміна, В.О. Степаненко та інших.

Виділення невирішених раніше частин загальної проблеми. Незважаючи на велику кількість досліджень системи державного боргу України, відкритими все ж залишаються питання його погашення.

Формування цілей статті. Метою нашого дослідження $є$ визначення принципів виникнення та динаміки державного боргу України, а також особливостей його погашення.

Виклад основного матеріалу дослідження. Державний борг, як важлива складова держав- 
Сутність поняття “державний борг”

\begin{tabular}{|c|l|}
\hline Вчений & \multicolumn{1}{|c|}{ Сутність поняття “державний борг” } \\
\hline М. Карлін & сутність усіх боргових зобов’язань держави перед своїми кредиторами. \\
\hline В. Федосова & $\begin{array}{l}\text { сума всіх випущених і непогашених боргових зобов’язань держави перед внутрішніми і } \\
\text { зовнішніми кредиторами, а також відсотків за ними. }\end{array}$ \\
\hline Ю. Воробйова & $\begin{array}{l}\text { борг безпосередньо держави, їі органів, установ, організацій та борг, що утворюеться } \\
\text { економічними суб’єктами країни, за якими держава надала гарантії або не надала гарантії, } \\
\text { але вимушена нести відповідний тягар. }\end{array}$ \\
\hline Т.П. Вахненко & $\begin{array}{l}\text { сума фрінансових зобов’язань сектора загального державного управління, які мають форору } \\
\text { договірних стосовно внутрішніх і зовнішніх кредиторів щодо відшкодування залучених } \\
\text { коштів та виплати відсотків (чи без такої виплати). }\end{array}$ \\
\hline
\end{tabular}

них фрінансів, сьогодні привертає увагу як зарубіжних, так і вітчизняних науковщів. Це пов'язано передусім із тим, що в сучасних складних умовах, коли впроваджуються реформи та заходи стабілізащії економічної та зовнішньополітичної ситуації в Україні, уряд здійснюе нові запозичення як на внутрішньому, так і на зовнішньому ринках.

Відповідно до ст. 2 Бюджетного Кодексу України, державний борг - загальна сума боргових зобов'язань держави 3 повернення отриманих та непогашених кредитів (позик) станом на звітну дату, що виникають внаслідок державного запозичення [1].

На сьогодні серед вчених економістів не існуе єдності думок щодо визначення сутності державного боргу. Так, одні дослідники вважають, що державний борг - це сума заборгованості за випущеними й непогашеними внутрішніми позиками, а інші - що державний борг - це сума накопичених зобов'язань держави, враховуючи відсотки за користування позиченими коштами. Погляди вчених щодо сутності поняття “державний борг" відображені в табл. 1.

Державний борг виступає важливим елементом ринкової економіки і залежно від системи формування запозичень його поділяють на внутрішній чи зовнішній борг (рис. 1). У реаліях української економіки державний борг тісно пов'язаний із економічною безпекою держави, адже поглиблює виникнення не лише фрінансових, а й соціально-політичних проблем.

Характерні особливості державного боргу:

- В основі змісту державного боргу лежать кредитно - фрінансові відносини з приводу залучення державою додаткових фрінансових ресурсів, тобто здійснення запозичень;

- Позичальником і боржником у цих відносинах є держава;

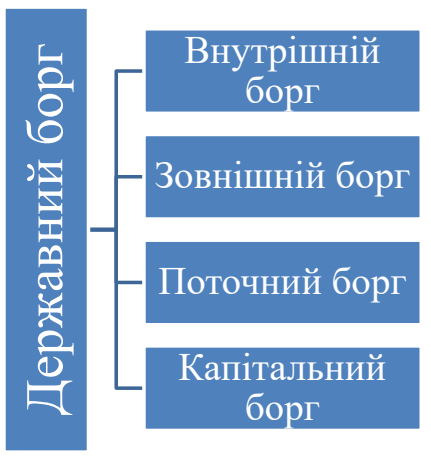

Рис. 1. Структура державного боргу
- Формою державних запозичень є державні цінні папери.

- Позичкові ресурси - це тимчасово вільні кошти юридичних та фрізичних осіб, іноземних держав, міжнародних організацій тощо.

Державний борг виникає через брак у держави коштів, необхідних для виконання їі фрункцій, серед яких регулювання економіки, проведення соціальної політики, забезпечення обороноздатності країни, утримання пенітенціарної системи, міжнародної діяльності. Тому держава змушена мобілізувати додаткові фінансові ресурси для покриття своїх видатків, необхідних для забезпе-

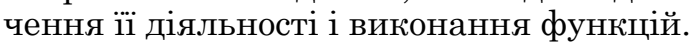

Розглянемо ситуацію 3 державним боргом в Україні на сучасному етапі та за останні роки. Так, у 2015 р. загальний державний борг України становив 1556,08 млрд. грн. У 2016p. державний борг України збільшився на $24,02 \%$ і становив 1929,81 млрд. грн., а вже станом на 2017 рік загальний державний борг знову зріс на 10,9\% і становив 2141,69 млрд. грн. На кінець 2018 року загальний державний борг знову збільшуеться до 2168,63 млрд. грн. Щодо 2019 року, то спостерігалося зменшення державного боргу на 7,9\%. Згідно найактуальніших даних Міністерства фpiнансів України, станом на 30 вересня 2019 року загальний державний борг України становив 2345,61 млрд. грн. (рис. 2).

3 рисунка видно, що протягом 2015-2018 рр. державний борг стабільно зростав, спричинене це було в основному через збільшення зовнішніх запозичень. У 2019 році загальний державний борг значно зменшився, проте на кінець 2020 року знову зріс.

Для повноцінної оцінки державного боргу варто згадати про граничний обсяг державного боргу. Відповідно до ст. 18 Бюджетного Кодексу України, граничний обсяг державного боргу і гарантованого державою боргу, граничний обсяг надання державних гарантій визначаються на кожний бюджетний період законом про Державний бюджет України (рішенням про місцевий бюджет). Загальний обсяг державного боргу та гарантованого державою боргу на кінещь бюджетного періоду не може перевищувати 60 відсотків річного номінального обсягу валового внутрішнього продукту України. У разі очікуваного перевищення ціеї граничної величини Кабінет Міністрів України невідкладно звертається до Верховної Ради України за дозволом на тимчасове перевищення такої граничної величини та подає для схвалення план заходів 3 приведення загального обсягу держав- 


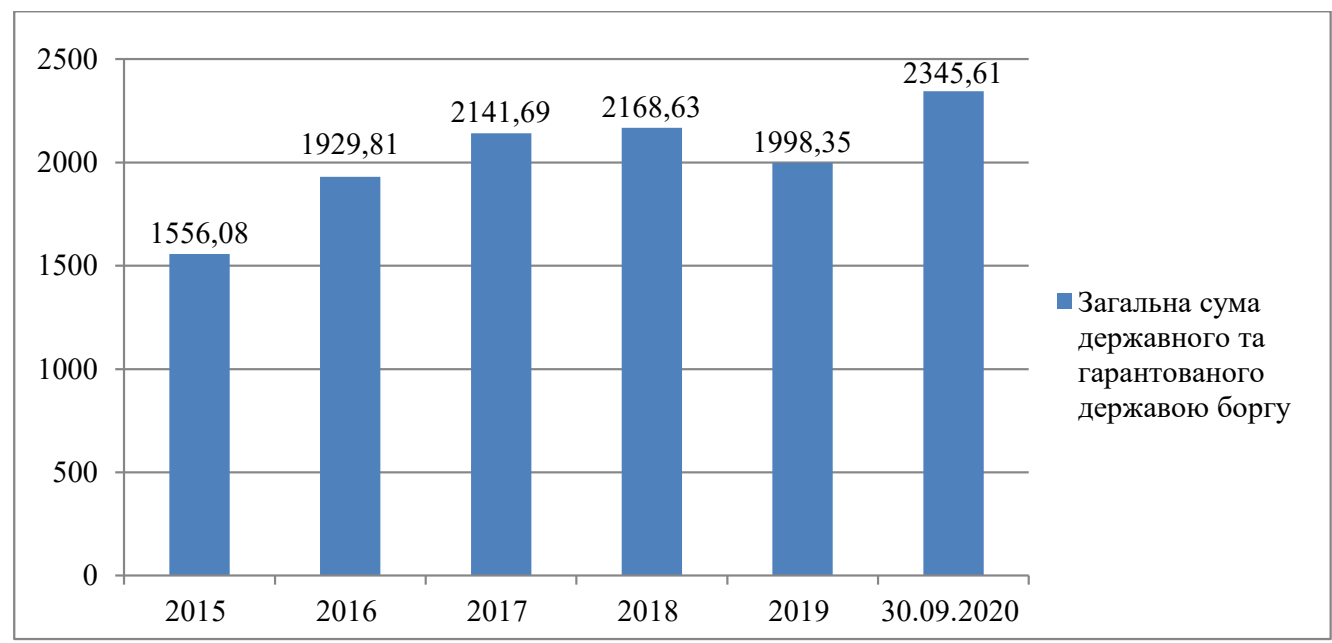

Рис. 2. Динаміка державного боргу України 2015-2019 рр. та 30.09.2020 р., млрд. грн

Джерело: розроблено авторами за даними [6]

ного боргу та гарантованого державою боргу до встановлених вимог [1].

Розглянемо яку частку у ВВП країни становить загальний обсяг державного боргу та гарантованого державою боргу на кінець бюджетного періоду (табл. 2).

Дослідивши частку загального обсягу державного боргу та гарантованого державою боргу у ВВП України, варто відмітити, що протягом 2015-2017 років даний показник значно перевищував затверджені у Бюджетному кодексі норми. Так, у 2015 році частка державного боргу у ВВП України становила 78,61\%, у 2016 році зросла до 80,98\%, у 2017 році дещо зменшилася до $71,79 \%$. У 2018 році частка державного боргу у ВВП України почала наближатися до нормативного значення, затвердженого Бюджетним кодексом, а вже у 2019 рощі даний показник становив 50,28\%, що знаходиться в рамках граничної величини державного боргу.

Щодо граничної величини державного боргу згідно найактуальніших даних, то у Законі про Державний бюджет на 2020 рік визначено, що на
31 грудня 2020 року граничний обсяг державного боргу становить 2386,79 млрд. грн.

Загальний державний борг в Україні сфрормований за рахунок зовнішніх та внутрішніх запозичень. Розглянемо структуру загального державного боргу (табл. 3).

Отже, дані таблищі свідчать, що у структурі державного боргу більшу частку займає зовнішній державний борг. Так, у 2015 р. частка зовнішнього державного боргу становила 65,98\% від всієї суми боргу, у 2016 р. зменшилася до $64,26 \%$, у 2017 р. ще зменшилася до 64,20\%. Проте, у 2018 р. частка зовнішнього державного боргу у сумі загального державного боргу зросла до 64,43\%. У 2019 році спостерігалось значне зменшення частки зовнішнього державного боргу до 58,02\%.

Якщо дослідити структуру загального державного боргу, то видно, що протягом досліджуваного періоду значно більшу частку займає зовнішній державний борг. Розглянемо структуру зовнішнього державного боргу (табл. 4).

Дослідивши структуру загального зовнішнього державного боргу України, варто відмітити,

\begin{tabular}{|l|c|c|c|c|c|}
\hline \multicolumn{1}{|c|}{ Показники } & $\mathbf{2 0 1 5}$ & $\mathbf{2 0 1 6}$ & $\mathbf{2 0 1 7}$ & $\mathbf{2 0 1 8}$ & $\mathbf{2 0 1 9}$ \\
\hline $\begin{array}{l}\text { Загальний обсяг державного боргу та } \\
\text { гарантованого державою боргу, млрд. грн. }\end{array}$ & 1556,08 & 1929,81 & 2141,69 & 2168,63 & 1998,35 \\
\hline Валовий внутрішній продукт, млрд. грн. & 1979,5 & 2383,18 & 2982,92 & 3558,71 & 3974,56 \\
\hline Частка державного боргу у ВВП України, \% & 78,61 & 80,98 & 71,79 & 60,94 & 50,28 \\
\hline
\end{tabular}

Джерело: розроблено авторами за даними [6]

Таблиця 3

Структура державного боргу України 2015-2019 рр., млрд. грн

\begin{tabular}{|l|c|c|c|c|c|}
\hline \multicolumn{1}{|c|}{ Показники } & $\mathbf{2 0 1 5}$ & $\mathbf{2 0 1 6}$ & $\mathbf{2 0 1 7}$ & $\mathbf{2 0 1 8}$ & $\mathbf{2 0 1 9}$ \\
\hline Загальний державний борг & 1556,08 & 1929,81 & 2141,69 & 2168,63 & 1998,35 \\
\hline Зовнішній державний борг & 1024,8 & 1240,08 & 1375,01 & 1397,22 & 1159,44 \\
\hline Внутрішній державний борг & 531,3 & 689,73 & 766,68 & 771,41 & 838,55 \\
\hline $\begin{array}{l}\text { Частка внутрішнього державного боргу } \\
\text { у сумі загального державного боргу }\end{array}$ & $34,12 \%$ & $35,74 \%$ & $35,80 \%$ & $35,57 \%$ & $41,97 \%$ \\
\hline $\begin{array}{l}\text { Частка зовнішнього державного боргу } \\
\text { у сумі загального державного боргу }\end{array}$ & $65,98 \%$ & $64,26 \%$ & $64,20 \%$ & $64,43 \%$ & $58,02 \%$ \\
\hline
\end{tabular}

Джерело: розроблено авторами за даними [6] 
Структура зовнішнього державного боргу України 2015-2019 рр., млрд. грн

\begin{tabular}{|l|c|c|c|c|c|}
\hline & $\mathbf{2 0 1 5}$ & $\mathbf{2 0 1 6}$ & $\mathbf{2 0 1 7}$ & $\mathbf{2 0 1 8}$ & $\mathbf{2 0 1 9}$ \\
\hline Зовнішній борг & 1024,8 & 1240,08 & 1375,01 & 1397,22 & 1998,35 \\
\hline $\begin{array}{l}\text { Заборгованість за позиками, одержаними від міжнародних } \\
\text { фінансових організацій }\end{array}$ & 471,9 & 562,78 & 637,18 & 607,74 & 483,05 \\
\hline $\begin{array}{l}\text { Заборгованість за позиками, одержаними від органів } \\
\text { управління іноземних держав }\end{array}$ & 37,66 & 50,63 & 52,04 & 49,28 & 38,59 \\
\hline $\begin{array}{l}\text { Заборгованість за позиками, одержаними від іноземних } \\
\text { комерційних банків, інших іноземних фінансових установ }\end{array}$ & 67,83 & 61,96 & 59 & 67,41 & 67,39 \\
\hline $\begin{array}{l}\text { Заборгованість за випущеними цінними паперами на } \\
\text { зовнішньому ринку }\end{array}$ & 404,88 & 517,80 & 574,46 & 622,37 & 527,53 \\
\hline Заборгованість, не віднесена до інших категорій & 42,64 & 47,87 & 52,34 & 50,47 & 42,89 \\
\hline
\end{tabular}

Джерело: розроблено авторами за даними [6]

що значну частку у зовнішній заборгованості держави становить заборгованість за позиками, одержаними від міжнародних фінансових організацій (наприклад, 46,05\% у 2015 році) та заборгованість за випущеними цінними паперами на зовнішньому ринку (наприклад, 39,51\% у 2015 році). Найменшою у структурі є заборгованість за позиками, одержаними від органів управління іноземних держав.

Щодо позик від зовнішніх організацій, то на сьогодні головними кредиторами України є такі міжнародні організації:

- Свропейське Співтовариство;

- Свропейський банк реконструкції та розвитку;

- Свропейський Інвестиційний Банк;

- Міжнародний банк реконструкції та розвитку;

- Міжнародний Валютний Фонд;

- Фонд чистих технологій (МБРР).

Небезпечною тенденщією бюджетної системи впродовж останніх років стало не лише нарощування загальних обсягів державного та гарантованого державою боргу України, а й суттеве зростання витрат бюджету на фрінансування його обслуговування та погашення (табл. 5).

3 таблиці 4 видно, що протягом досліджуваного періоду спостерігалось збільшення витрат на погашення та обслуговування державного боргу. Так, у 2015 році витрати на погашення державного боргу становили 416,58 млрд. грн., у 2016 році - зменшилися до 111,41 млрд. грн., у 2017 році знову зросли до 363,5 млрд. грн., проте у 2018 рощі дещо зменшилися до 234,47 млрд. грн. У 2019 році витрати на погашення державного боргу зросли до 345,2 млрд. грн.

Витрати на обслуговування державного боргу також збільшувалися протягом 2015-2019 років. Так, у 2015 році вони становили 84,51 млрд. грн., у 2016 році зросли на $13,35 \%$, у 2017 році знову зросли на 20,51\%. У 2018 році витрати на обслуговування державного боргу дещо зменшилися до 110,46 млрд. грн., проте у 2019 рощі зросли на 7,95\% до 119,25 млрд. грн.

В умовах зростання боргових зобов'язань держави видатки на їх обслуговування у подальших роках зростатимуть, що загострюватиме ризики розбалансування бюджетного фонду та скорочення фрінансування інших фрункцій держави [2].

Тому сьогодні існуючі боргові проблеми держави потребують удосконалення боргової політики України та побудови дієвої системи управління державним боргом. Основою цього повинно стати удосконалення нормативно-правового забезпечення, підвищення ефрективності інвестищійної складової бюджетних видатків та стратегічні завдання переорієнтації боргової політики, а також зменшення боргового тягаря та розвитку альтернативних, непозичкових інструментів фрінансування бюджетних видатків. Тобто комплексне вирішення проблеми зовнішнього державного боргу неможливе без едрективної системи управління державним боргом.

Під управлінням державним боргом слід розуміти сукупність заходів з регулювання його обсягу та структури, визначення умов здійснення нових запозичень, регулювання ринку державних запозичень, реалізащії заходів антикризового управління проблемними боргами, обслуговування і погашення боргу, визначення умов і надання державних гарантій, контролю за едрективним використанням запозичених коштів. Управління державним боргом здійснюеться через застосування наступних методів (табл. 6).

Для едективного управління державним боргом потрібно дотримуватись наступних принципів:

- безумовності (забезпечення режиму безумовного виконання державою всіх зобов'язань перед інвесторами і кредиторами);

- планування i прогнозування (прийняття рішень щодо управління державним боргом та гарантованим державою боргом на основі об-

Таблиця 5

Погашення та обслуговування державного боргу України 2015-2019 рр., млрд. грн

\begin{tabular}{|l|c|c|c|c|c|}
\hline \multicolumn{1}{|c|}{ Показники } & $\mathbf{2 0 1 5}$ & $\mathbf{2 0 1 6}$ & $\mathbf{2 0 1 7}$ & $\mathbf{2 0 1 8}$ & $\mathbf{2 0 1 9}$ \\
\hline Загальний державний борг & 1556,08 & 1929,81 & 2141,69 & 2168,63 & 1998,35 \\
\hline Погашення державного боргу & 416,58 & 111,41 & 363,5 & 234,47 & 345,2 \\
\hline Погашення державного внутрішнього боргу & 91,16 & 102,37 & 297,03 & 166,88 & 261,41 \\
\hline Погашення державного зовнішнього боргу & 325,42 & 9,04 & 66,47 & 67,59 & 83,79 \\
\hline Обслуговування державного боргу & 84,51 & 95,79 & 115,43 & 110,46 & 119,25 \\
\hline
\end{tabular}

Джерело: розроблено авторами за даними [4] 
Методи управління державним боргом

Таблиця 6

\begin{tabular}{|c|c|}
\hline $\begin{array}{l}\text { Метод управління } \\
\text { державним боргом }\end{array}$ & Характеристика методу \\
\hline редінансування державного боргу & $\begin{array}{l}\text { погашення основного тіла боргу і відсотків за рахунок коштів, отриманих } \\
\text { від розміщення нових боргових зобов'язань держави на внутрішньому та } \\
\text { зовнішньому фінансових ринках }\end{array}$ \\
\hline новація & $\begin{array}{l}\text { передбачає укладання угоди між позичальником та кредитором щодо } \\
\text { заміни одних боргових зобов'язань іншими }\end{array}$ \\
\hline уніфікація & $\begin{array}{l}\text { рішення держави стосовно об’єднання декількох, раніше випущених } \\
\text { позик, а також обмін раніше випущених облігацій і сертифікатів на } \\
\text { облігації та сертифрікати нових позик }\end{array}$ \\
\hline конверсія & зміна первинних умов державних позик і зміна рівня їх дохідності \\
\hline консолідація & $\begin{array}{l}\text { передбачає зміну умов запозичень у частині збільшення термінів } \\
\text { боргових зобов’язань }\end{array}$ \\
\hline відстрочка погашення позик & $\begin{array}{l}\text { являє собою застосування методу консолідації з одночасною відмовою } \\
\text { держави від сплати доходів за даними борговими зобов’язаннями }\end{array}$ \\
\hline анулювання державного боргу & передбачає відмову держави від раніше взятих на себе боргових зобов'язань \\
\hline реструктуризація & $\begin{array}{l}\text { перегляд умов обслуговування боргу, у тому числі щодо відсотків } \\
\text { кредиту, суми, термінів повернення; списання боргу }\end{array}$ \\
\hline дострокове погашення & $\begin{array}{l}\text { передбачає економію бюджетних коштів за необхідності їх майбутнього } \\
\text { обслуговування }\end{array}$ \\
\hline
\end{tabular}

Джерело: розроблено авторами за даними [9]

Iрунтованих планів і прогнозів потреби держави у фрінансових ресурсах);

- мінімізація ризиків (розміщення і погашення позик таким чином, щоби максимально знизити вплив коливань кон'юнктури світового ринку капіталів і спекулятивних тенденцій ринку цінних паперів на ринок державних зобов'язань);

- оптимальності структури (підтримання оптимальної структури боргових зобов'язань за термінами обертання і погашення);

- зберігання фрінансової незалежності (підтримка оптимальної структури боргових зобов'язань держави між інвесторами-резидентами і інвесторами-нерезидентами);

- прозорості та публічності інформації (дотримання відкритості при випуску позик, забезпечення доступу міжнародних рейтингових агентств до достовірної інформації про економічний стан у державі).

Україна, як і більшість країн світу, залучає кошти для виконання зобов'язань перед громадянами, проведення редорм та реалізацію інфрраструктурних проєктів. Важливо, щоб країна мала стійкий державний борг, тобто не нагромаджувала великих обсягів боргу по відношенню до ВВП і не мала в майбутньому проблем iз погашенням раніше взятих запозичень. Тому 14 листопада 2019 року Верховна Рада України в другому читанні та в цілому схвалила проект закону "Про внесення змін до Бюджетного кодексу України”, яким передбачається створення Боргового агентства України. На засіданні Уряду 12 лютого 2020 року було ухвалено постанову про створення агентства як центрального органу виконавчої влади та затверджено Положення про Агентство з управління державним боргом України. Створення Боргового агентства - необхідна умова виконання плану дій Уряду зі зменшення витрат платників податків на обслуговування боргів. Запуск діяльності агентства дозволить максимально оперативно та ефективно застосовувати інструменти із управління державним боргом в Україні [8].
Попри те, що здійснюються певні кроки на шляху до врегулювання проблеми державного боргу, дане питання все ж залишаеться невирішеним. Враховуючи свій і міжнародний досвід обслуговування державного боргу, на нашу думку, доцільно запропонувати такі заходи для врегулювання даної проблеми на українському ринку:

- Потрібно розробити дієві нормативно-законодавчі акти 3 питань регулювання ринку внутрішніх запозичень держави, де встановити нормативні співвідношення між обсягами емісії державних позик, їх дохідністю та величиною.

- Необхідно зменшити вартість позичкових коштів і відповідно вартість обслуговування державного боргу.

- Випуск державних позик повинен бути зумовлений не лише покриттям поточного деdріциту бюджету, а й інвестиційними потребами. Держава повинна фрінансувати продуктивні інвестиції. За рахунок коштів, залучених на ринку державних облігацій, в першу чергу слід фрінансувати галузі, розвиток яких сприятиме швидкому збільшенню виробничого та експортного потенціалу економіки України і зростанню ВВП. Від цього виграє як економіка, так і держава.

Крім того, проблеми державного боргу повинні стати окремим напрямом дослідження у сорерах економічного аналізу, прогнозування, фрінансового менеджменту, господарського права. До принципових моментів, на яких варто зосередити увагу при вироблені стратегї боргового управління, слід віднести чітко визначену граничну межу частки зовнішнього та внутрішнього боргу та витрат на їхне обслуговування в структурі державних витрат; подальше зниження вартості обслуговування державного боргу та подовження терміну запозичень, поєднання ринкових та інституціональних механізмів управління державним боргом тощо.

Висновки. У ході аналізу динаміки державного боргу України встановлено, що наразі небезпечним $є$ не тільки нарощування загальних обсягів державного і гарантованого державою 
боргу України, а й істотне зростання витрат бюджету на його обслуговування і погашення, які становлять значну частку у структурі витрат державного бюджету України. Тому сьогодні держава повинна вжити невідкладних заходів для мінімізації державного боргу та для його ефективного використання.

За останні роки рівень державного боргу України істотно зріс. Причиною џього є дисбаланс економіки, неефективне та нераціональне управління боргом, а також нівелювання державних цінностей.

Варто зазначити, що існування великого державного боргу може підірвати економічне зростання країни і негативно впливати на їі фрінансовий стан, зокрема: при великому внутрішньому боргу може проявитися й посилитися едрект витіснення приватних інвестицій, обслуговування зовнішнього державного боргу передбачає витік ресурсів 3 країни-боржника, велика зовнішня заборгованість може призвести національну економіку до серйозної економічної кризи, швидке зростання зовнішнього боргу може поставити країну в несприятливе залежне становище від кредиторів, знизити міжнародний авторитет країни і підірвати довіру населення до політики ії уряду, наявність державного боргу потребує здійснення щорічних відсоткових платежів, які повинні фрінансуватись за рахунок податкових надходжень тощо.

Але крім негативних наслідків, державні запозичення чинять позитивний вплив - це можливість використання запозичень як стимулу для внутрішніх капіталовкладень, за умови дії едрективного боргового менеджменту, що передбачає врахування динаміки валютного курсу та оцінку паритету процентних ставок на вітчизняному та міжнародному фінансових ринках.

Першочерговим завданням політики управління державним боргом $є$ забезпечення принципу ефрективного використання залучених коштів. Адже борги держави виправдані лише у випадках, якщо здійснювані за їх рахунок витрати сприяють збільшенню майбутніх бюджетних доходів.

\section{Список літератури:}

1. Бюджетний кодекс України № 467-IX від 16.01.2020 p. URL: http://zakon5.rada.gov.ua/laws/show/2456-17 (дата звернення: 01.12.2020).

2. Бондарук Т.Г., Бондарук О.С., Мельничук Н.Ю. Державний борг України та видатки бюджету на його обслуговування. Статистика України. 2018. № 1.

3. Доліновська О.Я., Ігнатюк А.І. Суперечливий характер впливу державного зовнішнього боргу на розвиток національної економіки. "Економічні науки». Серія "Облік і ббінанси». 2011. Випуск 8(29). Ч. 1.

4. Інформація про здійснення операцій з управління державним боргом. Державна казначейська служба України. URL: https://www.treasury.gov.ua/ua/file-storage/vikonannya-derzhavnogo-byudzhetu (дата звернення: 30.11.2020).

5. Руда О.Л. Державний борг України на сучасному етапі розвитку. Еконолічна наука. Еконоліка та держава. 2015. Вип. 3. C. 64-67. URL: http://www.economy.in.ua/pdf/3_2015/16.pdf (дата звернення: 03.12.2020).

6. Статистика державного боргу України. Міністерство фінансів України. URL: https://mof.gov.ua/uk (дата звернення: 04.12.2020)

7. Минфин. Офіційний сайт. ВВП України. URL: https://index.minfin.com.ua/ua/economy/gdp/ (дата звернення: 01.12.2020)

8. Міністерство фрінансів України. Офіційний сайт. Управління державним боргом виходить на якісно новий рівень. URL: https://mof.gov.ua/uk/news/upravlinnia_derzhavnim_borgom_vikhodit_na_iakisno_novii_ riven-2037 (дата звернення: 30.11.2020).

9. Скрипка О. Система управління зовнішнім державним боргом. Зовнішня торгівля: еконоліка, фбінанси, право. 2017. № 1. URL: http://zt.knute.edu.ua/files/2017/01(90)/ZT_01_2017_st_09.pdf (дата звернення: 04.12.2020).

\section{References:}

1. Budget Code of Ukraine № 467-IX dated 16.01.2020. URL: http://zakon5.rada.gov.ua/laws/show/2456-17 (accessed 1 December 2020).

2. Bondaruk T.G., Bondaruk O.S., Melnychuk N.Yu. (2018) Public debt of Ukraine and budget expenditures for its maintenance. Statistics of Ukraine, no. 1.

3. Dolinovskaya O.Ya., Ignatiuk A.I. (2011) Contradictory nature of the influence of public external debt on the development of the national economy. "Economic Sciences". Series "Accounting and Finance", issue 8(29), part 1.

4. Information on the implementation of public debt management operations. State Treasury Service of Ukraine. URL: https://www.treasury.gov.ua/en/file-storage/vikonannya-derzhavnogo-byudzhetu (accessed 30 November 2020).

5. Ruda O.L. (2015) State debt of Ukraine at the present stage of development. Economic Science. Economy and state, vol. 3, pp. 64-67. URL: http://www.economy.in.ua/pdf/3_2015/16.pdf (accessed 3 December 2020).

6. Statistics of public debt of Ukraine. Ministry of Finance of Ukraine. URL: https://mof.gov.ua/uk (accessed 4 December 2020).

7. Ministry of Finance. Official site. GDP of Ukraine. URL: https://index.minfin.com.ua/ua/economy/gdp/ (accessed 1 December 2020).

8. Ministry of Finance of Ukraine. Official site. Public debt management reaches a qualitatively new level. URL:https://mof.gov.ua/en/news/upravlinnia_derzhavnim_borgom_vikhodit_na_iakisno_novii_riven-2037(accessed 30 November 2020).

9. Skrypka O. (2017) External public debt management system. Foreign trade: economics, finance, law, no. 1. URL: http://zt.knute.edu.ua/files/2017/01(90)/ZT_01_2017_st_09.pdf (accessed 4 December 2020). 